\title{
Evaluation of steaming time on the colour and physical properties of four paddy rice varieties in West Africa
}

\section{Adegbola Oladele Dauda ${ }^{1}$, Hauwawu Hassan ${ }^{1}$, Adeshola A. Babayeju$^{1}$, John Kolade Joseph${ }^{1}$, Rachael Omowumi Oyelade ${ }^{2}$}

\author{
University of Ilorin, Ilorin, Nigeria \\ University of Ibadan, Ibadan, Nigeria
}

Keywords:

Rice

Steaming

Parboiling

Gelatinization

Article history:

Received 5.08.2021

Received in revised

form 16.11.2021

Accepted 30.12.2021

\section{Corresponding}

author:

Adegbola Oladele

Dauda

E-mail:

adegboladauda@

yahoo.com

DOI: $10.24263 / 2310$ -

1008-2021-9-2-7

\section{Abstract}

Introduction. Steaming in rice-parboiling causes gelatinization and protein disintegration in the endosperm changing its appearance and strength by fused gelatinized starch granules that disrupt protein bodies.

Materials and methods. Steaming-periods on grain strength and appearance of FARO64, FARO65, FARO66 and FARO67 rice varieties were evaluated. Each variety was divided into 5-parts; 4-parts parboiled and steamed for 5, 10, 15 and 20 mins (at constant temperature and atmospheric pressure), while the 5 th portion served as control.

Results and discussion. Steam application had a significant effect $(\mathrm{p}<0.05)$ on grain strength. Optimum strength was recorded at 20 mins steaming-period in FARO64, FARO65 and FARO66, while FARO67 had highest strength at 15 mins with values ranging from $61.53 \mathrm{~N}$ to $225.83 \mathrm{~N}$. FARO65 had reduced $\mathrm{L}^{*}$ value, though all varieties kept the yellow colour with the steaming-time. Only FARO64 maintained a* values with steaming-time. For length, FARO67 changed to very long, while FARO64, FARO65 and FARO66 changed from medium to long with a value range of between $6.33 \mathrm{~mm}$ and $7.57 \mathrm{~mm}$. The width values $(1.98-2.62 \mathrm{~mm})$ equally changed, as all varieties increased with steaming-time. All except FARO64 reduced in thickness with steaming-time. Shape of FARO64 changed from medium to slender; FARO65 and FARO66 maintained medium shape, while FARO67, from slender to medium. Thousand grain weights were between 15 and 24; FARO64, FARO66 and FARO67 had reduced mean-value, while FARO65 increased.

Conclusion. Parboiling reduces raw rice breakage rate, and improves strength, colour and appearance. Gelatinization temperature influences rice quality. 


\section{Introduction}

Rice is a staple food for about half of the world's population (Ebuehi et al., 2007); ranked as number one cereal; cooked and consumed in milled form (Hossain et al., 2009). Processing operations, pre-harvest to postharvest, affect milled rice quality, as over $90 \%$ of Nigerian rice is parboiled before consumption. Parboiling operations involves soaking, steaming and drying, as applied to rough rice for improved quality attributes, changes in milling properties, increase strength, while the protein denaturation diffuses into inter-granular space of starch, which further increases the binding effect for better milling process (Islam et al., 2004; Elbert et al., 2000). Steaming gelatinizes and concentrates nutrients on husk and bran layers, which then migrates inward through the solute via retrogradation process. Steamed rice becomes compact, thus making milling process easier since the husk's kernel is loose (Ayamdoo et al., 2013; Vikrant et al., 2018). Starch of the gelatinized and parboiled rice usually experience changes in appearance (Singh $e t$ al., 2000), eliminating the usual opaque portion in rice and making the end product more translucent and glossier than the un-parboiled rice.

Worldwide, rice is usually consumed as whole grain, where its physical properties such as colour, dimension and appearance determine quality, which are initial requirements for new rice variety in accordance to its size and shape, appearance, weight and uniformity (Varnamkhasti et al., 2008; Danbaba et al., 2012). Rice dimension, to a large extent, helps in equipment design for shape classification, selection of membrane size for optimal separation and in calculating machine milling efficiency (Singh et al., 2015). Rice length determines the breakage level, but steaming process better strengthened rice grain during parboiling, and reduced breakage (Kumar, 2013). Rice shape is usually determined via length and width ratio; however, its thickness (breath) reflects nutrient density, which invariably, amount to the physicochemical properties of the rice (Bocevska et al., 2009). For these parameters, rice is classified based on their length into very long $(>7.5 \mathrm{~mm})$, long $(<6.61 \mathrm{~mm})$, medium $(5.51-6.1 \mathrm{~mm})$ and short $(<5.5 \mathrm{~mm})$ and shapes with the use of length to width ratio (IRRI, 2009).

Rice users, either in the cooked or raw form, constantly emphasize particularly on the appropriate quality of rice. However, rice varieties vary in quality and properties with respect to plant and grain characteristics, plant type, height, nature of leaves, grain dimension, texture, starch content, colour, aroma, cooking properties and nutritive quality (Amaka $e t$ al., 2014), though each variety varies with specific optimum thermal treatment appropriate for its parboiling processes for high quality product (Igathinathane et al., 2005). Studying effect of steam application on the selected new indigenous rice varieties is very important for optimum quality and consumer acceptability, as adequate information on the new varieties is important to know whether they are comparable to those already in the market. Rice farmers, millers and consumers need adequate information on the quality of the indigenous new rice varieties. Based on these facts, this study aimed at evaluating the qualities of some new parboiled rice varieties steamed at various time-periods (using constant temperature and atmospheric pressure) in comparison with un-parboiled milled samples.

\section{Materials and methods}

\section{Sourcing of materials}

Four new rice varieties, FARO64, FARO65, FARO66 and FARO67 were obtained from the farms of National Cereals Research Institute, Badeggi, Niger State, Nigeria and processed according to the method of Danbaba et al. (2016) with slight modification in the use of different 
steaming periods $(5,10,15$ and 20 minutes $)$ at $100^{\circ} \mathrm{C}$ and atmospheric pressure, while the control sample was not parboiled.

\section{Sample preparation}

Rough rice was cleaned to remove dockages, and divided into five portions; four portions were packaged in a parboiling bag, soaked in hot water at $65^{\circ} \mathrm{C}$ for a period of 3 hours. It was then allowed to stand for $8 \mathrm{hrs}$ for conditioning before being steamed at $100^{\circ} \mathrm{C}$ (at atmospheric pressure) using an improved equipment (Water bath, TT-420.Techmel and Techmel, USA) that ensures uniform steam distribution between 5 and 20mins. Drying of the steamed samples was done at ambient temperature $\left(25 \pm 2^{\circ} \mathrm{C}\right)$ and atmospheric pressure to reduce moisture to between $13-14 \%$, and later milled using a laboratory model rubber roll rice huller (THU35B Satake ENGINEERING CORP, Tokyo, Japan) to de-husk into brown rice, which was polished in Rice-pal 32 (Yamamoto Co, Higashine, Japan) for a period of 3 mins (at Food Technology and Value Addition Programme Laboratory), National Cereals Research Institute, Badeggi, Niger State of Nigeria.

\section{Colour measurement}

Colour parameters $\left(L^{*}, a^{*}, b^{*}\right)$ of milled rice grain was determined with a colour meter (Konica Minolta, CM-3500d, Minolta Co., Ltd. Osaka, Japan), calibrated with a white standard plate (13371004), with illuminant D65 (CIE $196410^{\circ}$ Standard Observer) used. The colour coordinates, $L^{*}, a^{*}$ and $b^{*}$ were calculated in the CIELAB system. The $L^{*}$ values indicates lightness $(100=$ white and $0=$ black); $a^{*}$, the degree of red-green and $b^{*}$, level of yellow-blue colour, with higher $b^{*}$ indicating yellowness; replicate readings of 10 to eliminate variations.

\section{Strength of the rice samples}

The method of Sunday et al. (2018) was adopted for rice strength using a material testing machine (H50 K-S, Hounsfield, England). Briefly, a grain of rice sample was placed on a flat plate of the Instron testing machine, with tester handle turning continuously until $12 \mathrm{~mm}$ diameter probe pressed the grain with a $500 \mathrm{~N}$ load cell fixed parallel to the base at a cross-head speed of $1 \mathrm{~mm} / \mathrm{min}$, which cracks the grain under pressure. Applied force at initial break (rupture) was recorded from the digital computer as the yield point for each run. Five replicates were recorded for each sample.

\section{Measurement of grain dimension}

The grain dimension was measured with the method of the International Rice Research Institute (IRRI, 2009). Length, width and breath of randomly selected ten whole grains of milled rice was measured using digital Venire Caliper and grain shape determined through ratio of length to width of grains.

\section{Thousand grain weight}

The method of Varnamkhasti et al., 2008 was adopted for weight of a thousand grains, with random selection from bulk of rice grains, and weighed with sensitive weighing balance.

Statistical analysis 
Data from 20 rice samples were subjected to analysis of variance (ANOVA) using statistical package for social statistics (SPSS version 20.0); significant differences were compared with least significant difference (LSD) at 5\% level of probability, with chat on excel version 2010 (Microsoft cooperation, USA).

\section{Results and discussion}

\section{Colour of steamed milled rice}

Colour of rice grain is an important attribute of parboiled rice, which usually defines its quality before end users, as well as its market value. Normally, parboiled rice is amber in appearance, which could be darker depending on its physicochemical properties and applied heat during processing. Judging by this, it could be said that quality of parboiled rice is related to steaming time (Ebrahim et al., 2015), and from Table 1, whiteness ( $L^{*}$ value) of FARO64 steamed for 5-20mins during parboiling process was not significant $(\mathrm{p}<0.05)$ when compared with un-parboiled sample. The $L^{*}$ values ranged from 55.54 to 56.76 with steaming-time, and different from the reports of Islam et al. (2002); Singh et al. (2011); Chijoke et al. (2013) and Ebrahim et al. (2015), where they stated that temperature, soaking period, and steaming negatively influence whiteness of parboiled rice, but Amaka et al. (2014) had a contrary view. FARO64 $a^{*}$ parameters were greenish in colour and significantly different $(\mathrm{p}<0.05)$. Sample steamed for $5 \mathrm{mins}$, though had the highest $a^{*}$ value (-3.70), but not significantly different from samples steamed for 10 and 15 mins, and lesser than that of Amaka et al. (2014), that reported -1.01 to 1.52 . For the $b^{*}$ values, sample steamed for 20mins (31.92) was not significantly different from the other steamed samples but different significantly from the un-parboiled sample (28.90). The values increased with steaming-time $(30.08,30.76,31.18$ and 31.92) from 5 to 20mins respectively and equally higher than that of FARO61 (23.82) and FARO60 (18.15) as reported by Mayowa et al. (2017).

$L^{*}$ values of FARO65 samples exhibited erratic behaviours. The control sample was not significantly different from sample steamed for $10 \mathrm{mins}$, while samples steamed for 5,15 and 20 mins respectively showed no significant difference $(p<0.05)$ among themselves. The applied heat and genetic make-up of the variety could have caused the colour change, or could be attributed it to non-enzymatic browning reaction. The values obtained were in agreement with that of Prem et al. (2019) that worked on the effect of steaming on accelerated aging, and Sareepuang et al. (2008) that reported on the effect of steam temperature and time on rice parboiling. FARO65 showed varying colour for both un-parboiled and parboiled samples, with un-parboiled having a value of -6.84 and greenish colour. However, parboiled samples steamed at different time-periods were reddish in colour, though redness reduced in value with increased steaming (10mins to 20 mins) from 1.04 in sample steamed for $10 \mathrm{mins}$ to 0.30 at $20 \mathrm{mins}$, and significantly different $(\mathrm{P}<0.05)$ from one another. Ebrahim et al. $(2015)$ however stated differently that increasing steaming-time during rice parboiling caused increase in $a^{*}$ value. The degree of yellowness among FARO65 samples ranged from 28.90 to 27.66 for samples steamed for 10 and 20 mins respectively. The $b^{*}$ value increased from 28.10 in un-parboiled sample to 28.30 and 28.90 in samples steamed for 5 and $10 \mathrm{mins}$, and then decreased in samples steamed for 15 and 20mins, contrary to the report of Ebrahim et al. (2015), who reported complete increase in $b^{*}$ value (18.08 to 19.50). The reduction in the value at 15 and $20 \mathrm{mins}$ steaming periods could be due to the intense/prolonged heating period. 
Regarding FARO66, the un-parboiled sample recorded highest $L^{*}$ value (54.68), though not significantly different from sample steamed for 20mins. According to Islam et al., 2008, parboiling tends to darken or reduce lightness colour of parboiled milled rice. Samples steamed for 5 to $15 \mathrm{mins}$ were not significantly different $(\mathrm{p}<0.05)$ from one another, but were significant to that steamed for $20 \mathrm{mins}$, i.e. getting lighter with increasing steaming periods. This revealed that steaming application tends to increase its lightness value. For $a^{*}$ values, treated FARO66 samples were significantly different $(p<0.05)$ from the untreated one (low value of -5.70) with greenish colour. Samples steamed for 5, 10 and 20mins respectively were not different significantly from one another, but were significantly different from the sample steamed for $15 \mathrm{mins}$. Colour change noticed could be due to parboiling effect as earlier stated, which may be maillard type of non-enzymatic browning enhanced by the level of reducing sugar and amino acids during steaming, processing conditions during soaking and steaming, as well as husk pigment that diffused into the endosperm during soaking (Islam et al., 2002). During steaming, nutrients migrated into the endosperm from the husk and bran layer (Bloussi et al., 2010). The $b^{*}$ values ranged from 27.90 to 29.08 . The result showed that the controlled sample (untreated) and samples steamed for 10 and $15 \mathrm{mins}$ were not significantly different from one another, while sample steamed for $5 \mathrm{mins}$ was different from all the other samples, and comparable to that reported by Graham et al. (2015). It was noted that one of the parboiled rice samples had lowest $L^{*}$ value (dark) and the highest $b^{*}$ values (yellow) when treated and untreated samples were compared, and this could be attributable to soaking temperature and steaming-time or the effect of steaming on the genetic/agronomic properties of the paddy rice.

Significant difference $(\mathrm{p}<0.05)$ was observed in the $L^{*}$ values among FARO67 samples (steamed and un-steamed). Sample steamed for 20mins had the lowest value (52.44), while the highest value (54.80) was recorded with $15 \mathrm{mins}$ steaming. The low value of samples steamed for $20 \mathrm{mins}$ may be due to the high steam heat that might have darkened the colour of the milled rice (Graham et al., 2015). Sample steamed for 5 and 15mins, as well as the control sample were not significantly different from one another, likewise samples steamed for 10 and 20mins. Lightness value decreased with increased steaming-time, except in the 15 mins steaming. The $a^{*}$ values of FARO67 were significant. Un-parboiled sample was significantly different $(p<0.05)$ from the treated samples. Colour of parboiled rice changed gradually from greenish to reddish with increase in steaming-time, but changed after $15 \mathrm{mins}$. Un-parboiled sample of FARO67 was greenish (-6.10) in colour, but samples steamed for 10 and $15 \mathrm{mins}$ were reddish and similar, while samples steamed for 20 and $5 \mathrm{mins}$ respectively were greenish in colour (-0.06 and -022). It could be concluded that longer steaming period in rice parboiling had negative effect on $a^{*}$ value of processed rice, which could be attributable to genetic make-up according to Islam et al., 2002. FARO67 samples were not necessarily significant for $b^{*}$ values. According to Lamberts et al., 2008, high heat treatment during parboiling caused reduction in carotenoids of raw rice and maillard reaction and imparting yellow colour to the samples. It could be said generally that steaming had great effect on the colour attributes (either through the genetic make-up or agronomic properties) of the rice varieties. 
Effect of Steaming-Time on the Colour of parboiled rice

\begin{tabular}{|c|c|c|c|c|c|}
\hline Sample & $\begin{array}{c}\text { Rice } \\
\text { variety }\end{array}$ & $\begin{array}{c}\text { Steaming } \\
\text { period }\end{array}$ & $\mathbf{L}^{*}$ & $a^{*}$ & $\mathbf{b}^{*}$ \\
\hline 64 & \multirow{5}{*}{ FARO64 } & Non parboiled & $55.54 \pm 0.09^{a}$ & $-6.46 \pm 0.05^{f}$ & $28.90 \pm 0.07^{b c}$ \\
\hline 564 & & 5 & $55.36 \pm 0.01^{\mathrm{a}}$ & $-3.70 \pm 0.02^{\mathrm{e}}$ & $30.08 \pm 0.04^{\mathrm{ab}}$ \\
\hline 1064 & & 10 & $56.34 \pm 0.1^{\mathrm{a}}$ & $-3.98 \pm 0.02^{\mathrm{e}}$ & $30.76 \pm 0.02^{\mathrm{ab}}$ \\
\hline 1564 & & 15 & $56.66 \pm 0.1^{\mathrm{a}}$ & $-3.92 \pm 0.06^{\mathrm{e}}$ & $31.18 \pm 0.14^{\mathrm{a}}$ \\
\hline 2064 & & 20 & $56.76 \pm 0.15^{\mathrm{a}}$ & $-4.56 \pm 0.03^{f}$ & $31.92 \pm 0.07^{\mathrm{a}}$ \\
\hline 65 & \multirow{5}{*}{ FARO65 } & Non parboiled & $54.70 \pm 0.15^{b}$ & $-6.84 \pm 0.06^{f}$ & $28.10 \pm 0.05^{b c}$ \\
\hline 565 & & 5 & $52.12 \pm 0.09^{c}$ & $0.92 \pm 0.07^{\mathrm{a}}$ & $28.30 \pm 0.07^{\mathrm{bc}}$ \\
\hline 1065 & & 10 & $54.32 \pm 0.21^{\mathrm{b}}$ & $1.04 \pm 0.03^{\mathrm{a}}$ & $28.90 \pm 0.10^{b c}$ \\
\hline 1565 & & 15 & $51.48 \pm 0.19^{C}$ & $0.60 \pm 0.02^{b}$ & $27.28 \pm 0.09^{\mathrm{c}}$ \\
\hline 2065 & & 20 & $51.70 \pm 0.22^{\mathrm{C}}$ & $0.30 \pm 0.03^{\mathrm{c}}$ & $27.66 \pm 0.14^{\mathrm{c}}$ \\
\hline 66 & \multirow{5}{*}{ FARO66 } & Non parboiled & $54.68 \pm 0.05^{b}$ & $-5.70 \pm 0.02^{f}$ & $28.62 \pm 0.01^{b c}$ \\
\hline 566 & & 5 & $51.70 \pm 0.29^{\mathrm{C}}$ & $0.84 \pm 0.06^{\mathrm{a}}$ & $27.90 \pm 0.11^{\mathrm{c}}$ \\
\hline 1066 & & 10 & $51.16 \pm 0.29^{\mathrm{C}}$ & $0.88 \pm 0.05^{\mathrm{a}}$ & $28.58 \pm 0.18^{\mathrm{bc}}$ \\
\hline 1566 & & 15 & $52.20 \pm 0.20^{c}$ & $0.64 \pm 0.05^{\mathrm{b}}$ & $28.36 \pm 0.0^{\mathrm{bc}}$ \\
\hline 2066 & & 20 & $54.32 \pm 0.35^{\mathrm{b}}$ & $0.86 \pm 0.05^{\mathrm{a}}$ & $29.08 \pm 0.17^{b}$ \\
\hline 67 & \multirow{5}{*}{ FARO67 } & Non parboiled & $53.92 \pm 0.05^{b}$ & $-6.10 \pm 0.09^{f}$ & $28.16 \pm 0.03^{b c}$ \\
\hline 567 & & 5 & $53.88 \pm 0.11^{\mathrm{b}}$ & $-0.22 \pm 0.08^{d}$ & $29.24 \pm 0.04^{\mathrm{b}}$ \\
\hline 1067 & & 10 & $52.90 \pm 0.21^{\mathrm{c}}$ & $0.40 \pm 0.04^{\mathrm{b}}$ & $28.58 \pm 0.08^{\mathrm{bc}}$ \\
\hline 1567 & & 15 & $54.80 \pm 0.33^{b}$ & $0.40 \pm 0.02^{\mathrm{b}}$ & $29.14 \pm 0.09^{b}$ \\
\hline 2067 & & 20 & $52.44 \pm 0.24^{\mathrm{c}}$ & $-0.06 \pm 0.03^{\mathrm{cd}}$ & $28.12 \pm 0.14^{\mathrm{bc}}$ \\
\hline
\end{tabular}

\section{Effect of Steaming-Time on the Strength of Parboiled Milled Rice Samples}

Steaming operation in rice parboiling improves the quality of rough rice by sealing cracks in rice kernel (hardened) to resist milling forces, thus reducing rice breakage during milling. It gives high milling recovery, better market value, higher price and increases demand comparable to the un-parboiled grain, as end users demand for physical, cooking and eating qualities of parboiled rice achievable only by steam application (Islam et al., 2004; Graham et al., 2015; Farah et al., 2017). Strength of improved parboiled indigenous milled rice varieties (FARO64, FARO65, FARO66 and FARO67) from steam application is shown in Figure 1. Steam application was significant on the strength of the rice studied, as FARO65 steamed for $20 \mathrm{mins}$ had higher strength value $(205.01 \mathrm{~N})$ compared with $61.53 \mathrm{~N}$ for the control sample of same variety, and other treated samples. The higher energy value observed for the sample steamed for 20mins was not different from that of Marshall et al. (1993) that stated that parboiling increases hardness of rice, thus given higher head rice recovery, which may be attributable to the gelatinization and compactness of endosperm starch of parboiled rice that hardens rice kernel (Yuji et al., 2001). 


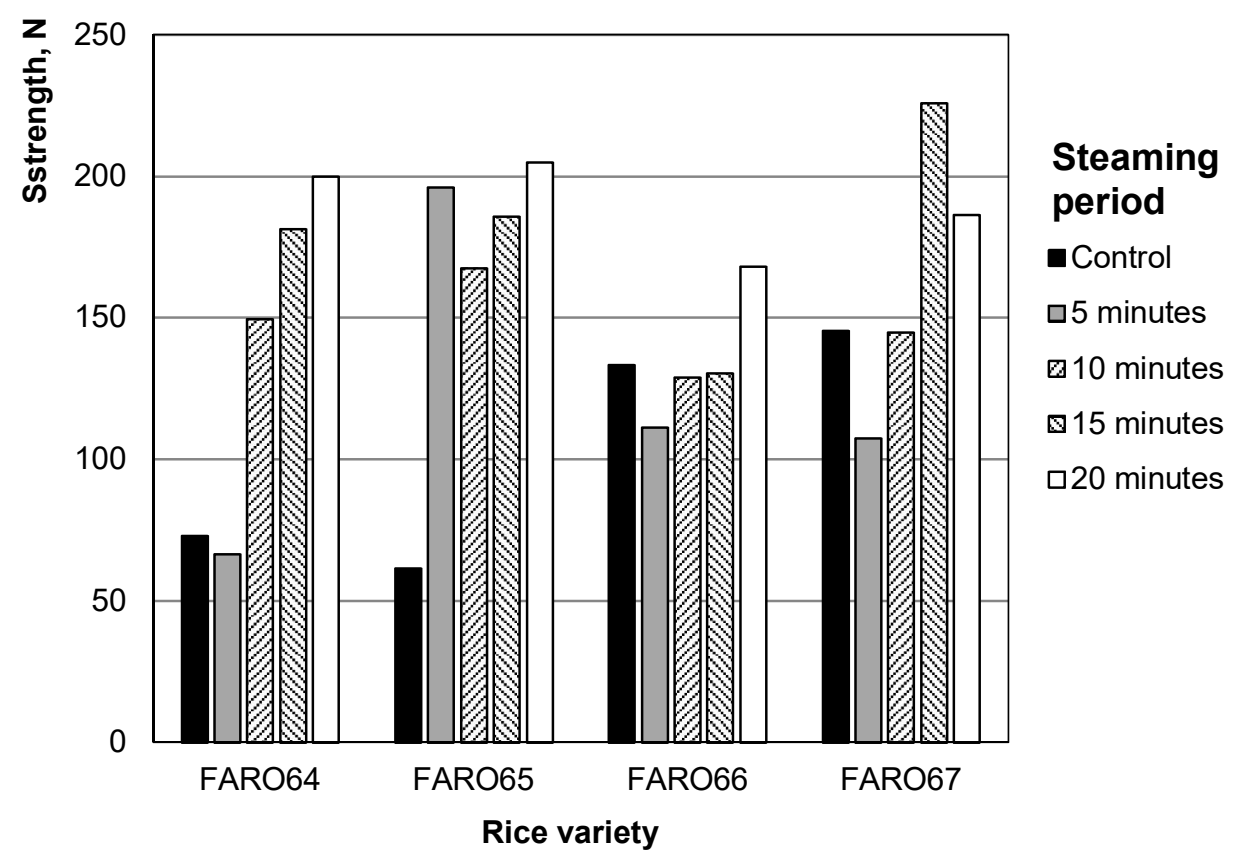

Figure 1. Effect of steaming-time on the strength of parboiled milled rice samples

For FARO64, it was obvious that steam had great effect as the strength increases with steaming, though at 5mins steaming, it was lesser than that of the un-parboiled, probably the sample may be adjusting to the steaming effect or genetic make-up of the variety. FARO65 samples steamed for 5-20mins were not significantly $(\mathrm{p}<0.05)$ different in strength from one another just as Ebrahim et al. (2015) reported that slightly different energies are required to break rice samples steamed between $2-10$ mins. Though slightly different energies would be required, they are not significantly different, but significantly different from the controlled sample. In FARO64, strength significantly ranged from $199.87 \mathrm{~N}$ in 20 mins steamed sample to $66.46 \mathrm{~N}$ in $5 \mathrm{mins}$ steamed sample. Sample steamed for between 10 and $20 \mathrm{mins}$ were significantly different $(\mathrm{P}<0.05)$ from the samples steamed for $5 \mathrm{mins}$ and the control $(73.06 \mathrm{~N})$. The expectation, according to Houssou et al., 2016, is to increase strength and harden grain with steaming process. However, short time steaming and low gelatinization process weakens starch cells and reduced grain strength (Ebrahim et al., 2015), and according to Islam et al., 2000, energy is required to break rice sample. Energy reported for samples steamed between 10 and 20 mins were $149.46 \mathrm{~N}, 181.37 \mathrm{~N}$ and $199.87 \mathrm{~N}$.

For FARO67, the strength varied significantly $(\mathrm{p}<0.05)$ from 107.39 to $225.83 \mathrm{~N}$ for treated samples, though the un-parboiled sample had energy $145.54 \mathrm{~N}$, which was higher than that steamed for 5mins. Grain strength/hardness of samples steamed for 15 and $20 \mathrm{mins}$ were higher than the control sample, which was not totally in agreement with the reports of Ebrahim et al., 2015 and Islam et al., 2000. Rice strength is important because rice hardness facilitate high head rice yield and minimized breakages during milling, ultimate goal of rice processors and millers. 
FARO66 sample steamed for 5mins had the lowest hardness value $(111.40 \mathrm{~N})$, attributable to weakness of starchy endosperm resulting from the effect of melting during initial gelatinization, and/or partial gelatinization. It was equally noticed that samples steamed for 10 and $15 \mathrm{mins}$, as well as the control were significantly not different from one another, defying the report of Ebrahim et al., 2015 and Islam et al., 2000. Rice with low energy has low resistance to breakage during milling leading to low percentage of head rice yield, which is of poor economic value and as such, FARO66 could be categorized as such. Steaming beyond 10mins, and up to $20 \mathrm{mins}$, increased hardness value from $111.40 \mathrm{~N}$ to $167.99 \mathrm{~N}$, supporting the report of Adekoye et al., 2014 that hardness of improved rice varieties increases with increase in steaming-time leading to extended shelf life. Hardness of the grains was not identical probably due to genetic make-up or agronomic properties of the varieties.

\section{Effect of steaming-time on physical properties of parboiled milled rice}

Rice is mostly consumed as whole grain, and as such, its dimensions such as length, width and thickness are considered, because of their importance in developing new rice variety for commercial production and selection preference by consumers (Adekoni et al., 2014). A significant increase $(\mathrm{P}<0.05)$ in length of FARO64 was observed, with $6.54 \mathrm{~mm}$, $6.73 \mathrm{~mm}, 7.57 \mathrm{~mm}$ and $7.30 \mathrm{~mm}$ respectively for samples steamed for 5 to $20 \mathrm{mins}$, while unparboiled sample was $6.05 \mathrm{~mm}$ (Table 2). Samples steamed for 5 and $10 \mathrm{mins}$ were not significantly different from each other but different from the un-parboiled/control sample. Likewise, samples steamed for 15 and 20 mins were also not significantly different $(\mathrm{P}<0.05)$ from each other, but significantly different $(\mathrm{P}<0.05)$ from the un-parboiled sample. Based on IRRI (2009) grain dimensional classification, it was discovered that FARO64 variety changed from medium to long grain size with steaming-time. FARO65 was significant for length. The value increased from 6.02 to $6.90 \mathrm{~mm}$ in the treated samples, as against $5.63 \mathrm{~mm}$ recorded for control sample. Sample steamed for 10 to $20 \mathrm{mins}$ were not significantly different from one another, and longer than the other two, but 5 mins steaming was shorter, implying that steaming increases length of FARO65, and could be termed a medium sized grain after parboiling. Significant difference $(\mathrm{p}<0.05)$ was not observed in the length of FARO66 treated samples. The mean length of the steamed samples ranged between $6.67-7.17 \mathrm{~mm}$, while the control sample was $6.33 \mathrm{~mm}$. The results were similar to that reported by Danbaba et al. (2016) on the processing characteristics, grain quality and end-use quality of hybrids and improved rice. Sample steamed for $15 \mathrm{mins}$ had the highest mean value, while that steamed for $5 \mathrm{mins}$ had the least length (treated). A reduced value of $6.90 \mathrm{~mm}$ was recorded in the sample steamed for 20mins, and consumers prefer long grains. As a result, FARO66 should be steamed for not more than 15mins for optimum length. In FARO67, no significant difference $(p<0.05)$ was observed for length (treated samples). During steaming, the length increased with increase in steaming-time $(7.23,7.53,7.58$ and $7.67 \mathrm{~mm})$ as against $6.79 \mathrm{~mm}$ recorded for un-parboiled sample, similar to that of Amaka et al. (2014) on TOX 3145 rice grains. Sample steamed for $20 \mathrm{mins}$ had the highest mean value of $7.67 \mathrm{~mm}$, making FARO67 increase in length with increased steaming-time. Though it increased with steaming time; it was not as long as pausa Basmati 1121, which was $8.3 \mathrm{~mm}$ (Kumar 2013).

The width value of FARO64 samples were not significantly different $(\mathrm{P}<0.05)$ from one other (treated and untreated). Steaming between 10 and 20mins resulted in slight increase in width from 2.57 to $2.62 \mathrm{~mm}$ in the samples. FARO65 samples were equally not significant for width (treated and untreated). Highest width value $(2.61 \mathrm{~mm})$ was recorded in the samples steamed for 15 and 20mins, while un-parboiled and 5 mins steamed samples were slightly 
less, meaning that steaming does not really affect width, but steaming between 15 and $20 \mathrm{mins}$ maximum should be adopted. The width dimension of FARO66 ranged from $2.31-2.61 \mathrm{~mm}$ and showed significant differences $(\mathrm{p}<0.05)$. Samples steamed for $5 \mathrm{mins}$ and the control were not significantly different from each other, but were significantly different $(p<0.05)$ from samples steamed for 10,15 and 20mins. However, samples steamed between 10 and $20 \mathrm{mins}$ were different from one another.

Significant differences $(\mathrm{P}<0.05)$ were observed for the width values of FARO67 samples, with values ranging from $1.96-2.37 \mathrm{~mm}$. Un-parboiled sample had a width value of $1.98 \mathrm{~mm}$, which was not significantly different from the sample steamed for $20 \mathrm{mins}$, samples steamed for 5 and $15 \mathrm{mins}$ were equally not different from each other, while the sample steamed for 10mins was different from the other samples. The width of FARO67 did not follow the pattern of the other varieties, but erratic.

Ratio of length to width of rice grains is an important attribute in shape determination (Joseph et al., 2015; Anounye et al., 2016). The length/width ratio of FARO64 was not significantly different $(\mathrm{p}<0.05)$, with values between $2.37-2.89 \mathrm{~mm}$. With $5 \mathrm{mins}$ steaming, length/width ratio was 2.61 compared to 2.37 recorded for un-parboiled sample. Samples steamed for 15 and 20mins had highest ratios (2.89 and 2.81), which was within the range of $1.71-3.56 \mathrm{~mm}$ reported by Joseph (2015) for some varieties of African rice. From the results, there was no significant change in the shape of the treated and untreated samples of FARO64, as they all maintained medium shape (IRRI, 2004). Length to width ratio of FARO65 showed significant difference $(\mathrm{P}<0.05)$. It increased with increase in steaming-time and ranged between 2.35 to 2.64 for steamed samples, but un-steamed sample had 2.30. Fofana et al. (2011) reported a slender shape for Benin Republic rice samples with ratio of 3.51, while improved varieties were reported to have medium shape with ratio of 2.69. Base on this, FARO65 could be classified as medium shaped and does not change with steaming-time just as FARO64 varieties. Length/width ratio of FARO66 samples were not significantly different $(\mathrm{p}<0.05)$, however, highest ratio $(2.88)$ was recorded with sample steamed for $5 \mathrm{mins}$, while the lowest was 2.64 recorded in the sample steamed for $20 \mathrm{mins}$, as against 2.74 recorded for un-parboiled sample. The length to width ratio of FARO66 reduced with increase in the steaming-time during parboiling except from 5 t0 10mins, though maintained medium shape throughout the steaming-periods. The values recorded were lower than 2.96 reported by Kumar (2013). Length to width ratio of FARO67 samples were significantly different $(\mathrm{p}<0.05)$ with steaming-time. Values of length/width ratio ranged from 2.58-3.56, with the sample steamed for $20 \mathrm{mins}$ recording the lowest ratio (2.58), while the un-parboiled sample had the highest (3.56). Samples steamed for $5 \mathrm{mins}$ had the highest ratio (3.45) among the steamed samples, a value similar to 3.51 reported by Anounye et al. (2016) in un-parboiled sample of FARO46 (slender shaped), while OFADA had length/width ratio of 2.35-2.44. As a result, FARO67 could be said to change shape with increased steaming from slender to medium.

Grain thickness level helps in designing milling machine, sieve selection and the calculation of milling power (Varnamkhasti et al., 2008). Thickness of FARO64 variety ranged from 1.76 to $2.03 \mathrm{~mm}$, with $20 \mathrm{mins}$ steamed sample having the highest value $(2.03 \mathrm{~mm})$, and the lowest value $(1.76 \mathrm{~mm})$, was observed in the sample steamed for $5 \mathrm{mins}$, though not significantly different from one another. It could be said that thickness of FARO64 rice variety increased with increased steaming-time. Un-parboiled FARO65 sample was $1.71 \mathrm{~mm}$ thick, while lower values of $1.62 \mathrm{~mm}, 1.59 \mathrm{~mm}$ and $1.69 \mathrm{~mm}$ were recorded for samples steamed between 5 and 20mins. For better percentage thickness of FARO65 variety, steaming for not less than $15 \mathrm{mins}$ during parboiling should be adopted. 
Effect of steaming-time on dimension of parboiled milled rice

\begin{tabular}{|c|c|c|c|c|c|c|c|}
\hline 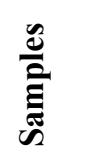 & 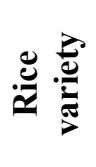 & 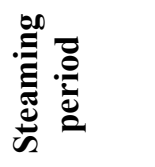 & 芯 & $\sum^{0}$ & 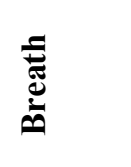 & 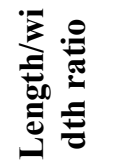 & $\begin{array}{c}1000 \text { grain } \\
\text { weight of } \\
\text { parboiled milled } \\
\text { rice }\end{array}$ \\
\hline 64 & \multirow{5}{*}{ 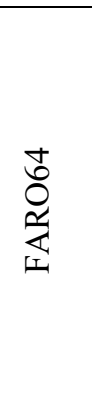 } & $\begin{array}{c}\text { Non } \\
\text { parboiled }\end{array}$ & $\begin{array}{c}6.05 \\
\pm 0.01^{d}\end{array}$ & $\begin{array}{c}2.55 \\
\pm 0.01^{\mathrm{a}}\end{array}$ & $\begin{array}{c}1.89 \\
\pm 0.00^{\text {ab }}\end{array}$ & $\begin{array}{c}2.37 \\
\pm 0.00^{\mathfrak{c}}\end{array}$ & $\begin{array}{c}15.67 \\
\pm 0.02^{d}\end{array}$ \\
\hline 564 & & 5 & $\begin{array}{c}6.54 \\
\pm 0.01^{\mathrm{c}}\end{array}$ & $\begin{array}{c}2.51 \\
\pm 0.00^{\mathrm{a}}\end{array}$ & $\begin{array}{c}1.76 \\
\pm 0.00^{\mathrm{b}}\end{array}$ & $\begin{array}{c}2.61 \\
\pm 0.00^{\mathrm{bc}}\end{array}$ & $\begin{array}{c}24.00 \\
\pm 0.10^{\mathrm{a}}\end{array}$ \\
\hline 1064 & & 10 & $\begin{array}{c}6.73 \\
\pm 0.00^{\mathrm{bc}}\end{array}$ & $\begin{array}{c}2.57 \\
\pm 0.00^{\mathrm{ab}}\end{array}$ & $\begin{array}{c}1.79 \\
\pm 0.00^{\mathrm{b}}\end{array}$ & $\begin{array}{c}2.62 \\
\pm 0.00^{\mathrm{c}}\end{array}$ & $\begin{array}{c}18.67 \\
\pm 0.06^{\mathrm{c}}\end{array}$ \\
\hline 1564 & & 15 & $\begin{array}{c}7.57 \\
\pm 0.00^{\mathrm{a}}\end{array}$ & $\begin{array}{c}2.60 \\
\pm 0.01^{\mathrm{a}}\end{array}$ & $\begin{array}{c}1.87 \\
\pm 0.00^{\mathrm{ab}}\end{array}$ & $\begin{array}{c}2.89 \\
\pm 0.01^{\mathrm{bc}}\end{array}$ & $\begin{array}{c}18.00 \\
\pm 0.00^{\mathrm{c}}\end{array}$ \\
\hline 2064 & & 20 & $\begin{array}{c}7.30 \\
\pm 0.04^{\mathrm{ab}}\end{array}$ & $\begin{array}{c}2.62 \\
\pm 0.00^{\mathrm{a}}\end{array}$ & $\begin{array}{c}2.03 \\
\pm 0.01^{\mathrm{a}}\end{array}$ & $\begin{array}{c}2.81 \\
\pm 0.01^{\mathrm{bc}}\end{array}$ & $\begin{array}{c}17.67 \\
\pm 0.06^{c}\end{array}$ \\
\hline 65 & \multirow{5}{*}{$\begin{array}{l}n \\
0 \\
0 \\
\substack{1 \\
1}\end{array}$} & $\begin{array}{c}\text { Non } \\
\text { parboiled }\end{array}$ & $\begin{array}{c}5.63 \\
\pm 0.02^{\mathrm{e}} \\
\end{array}$ & $\begin{array}{c}2.45 \\
\pm 0.00^{\text {ab }} \\
\end{array}$ & $\begin{array}{c}1.71 \\
\pm 0.01^{b} \\
\end{array}$ & $\begin{array}{c}2.30 \\
\pm 0.01^{d} \\
\end{array}$ & $\begin{array}{c}15.00 \\
\pm 0.00^{d}\end{array}$ \\
\hline 565 & & 5 & $\begin{array}{c}6.02 \\
\pm 0.02^{\mathrm{d}}\end{array}$ & $\begin{array}{c}2.57 \\
\pm 0.00^{\mathrm{a}}\end{array}$ & $\begin{array}{c}1.62 \\
\pm 0.00^{\mathrm{bc}}\end{array}$ & $\begin{array}{c}2.35 \\
\pm 0.01^{\mathrm{d}}\end{array}$ & $\begin{array}{c}16.00 \\
\pm 0.00^{\mathrm{h}}\end{array}$ \\
\hline 1065 & & 10 & $\begin{array}{c}6.63 \\
\pm 0.02^{\mathrm{bc}}\end{array}$ & $\begin{array}{c}2.58 \\
\pm 0.00^{\mathrm{a}}\end{array}$ & $\begin{array}{c}1.59 \\
\pm 0.00^{\mathrm{c}}\end{array}$ & $\begin{array}{c}2.57 \\
\pm 0.01^{\mathrm{c}}\end{array}$ & $\begin{array}{c}15.83 \\
\pm 0.03^{\mathrm{d}}\end{array}$ \\
\hline 1565 & & 15 & $\begin{array}{c}6.77 \\
\pm 0.00^{\mathrm{bc}}\end{array}$ & $\begin{array}{c}2.61 \\
\pm 0.00^{\mathrm{a}}\end{array}$ & $\begin{array}{c}1.69 \\
\pm 0.00^{\mathrm{bc}}\end{array}$ & $\begin{array}{c}2.59 \\
\pm 0.00^{\mathrm{c}}\end{array}$ & $\begin{array}{c}16.00 \\
\pm 0.00^{\text {cd }}\end{array}$ \\
\hline 2065 & & 20 & $\begin{array}{c}6.90 \\
\pm 0.01^{\mathrm{b}}\end{array}$ & $\begin{array}{c}2.61 \\
\pm 0.00^{\mathrm{a}}\end{array}$ & $\begin{array}{c}1.69 \\
\pm 0.00^{\mathrm{bc}}\end{array}$ & $\begin{array}{c}2.64 \\
\pm 0.00^{c} \\
\end{array}$ & $\begin{array}{c}16.93 \\
\pm 0.01^{\mathrm{cd}}\end{array}$ \\
\hline 66 & \multirow{5}{*}{ 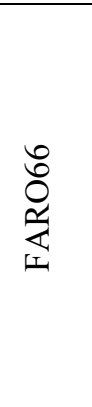 } & $\begin{array}{c}\text { Non } \\
\text { parboiled }\end{array}$ & $\begin{array}{c}6.33 \\
\pm 0.01^{\mathrm{c}}\end{array}$ & $\begin{array}{c}2.31 \\
\pm 0.00^{b}\end{array}$ & $\begin{array}{c}1.57 \\
\pm 0.00^{\mathbf{c}}\end{array}$ & $\begin{array}{c}2.74 \\
\pm 0.01^{\text {bc }}\end{array}$ & $\begin{array}{c}17.33 \\
\pm 0.06^{c}\end{array}$ \\
\hline 566 & & 5 & $\begin{array}{c}6.67 \\
\pm 0.02^{\mathrm{abc}}\end{array}$ & $\begin{array}{c}2.32 \\
\pm 0.00^{\mathrm{b}}\end{array}$ & $\begin{array}{c}1.26 \\
\pm 0.06^{\mathrm{d}}\end{array}$ & $\begin{array}{c}2.88 \\
\pm 0.01^{\mathrm{bc}}\end{array}$ & $\begin{array}{c}16.00 \\
\pm 0.00^{\text {cd }}\end{array}$ \\
\hline 1066 & & 10 & $\begin{array}{c}7.07 \\
\pm 0.00^{\mathrm{ab}}\end{array}$ & $\begin{array}{c}2.49 \\
\pm 0.00^{\mathrm{a}}\end{array}$ & $\begin{array}{c}1.61 \\
\pm 0.00^{\mathrm{bc}}\end{array}$ & $\begin{array}{c}2.83 \\
\pm 0.00^{\mathrm{bc}}\end{array}$ & $\begin{array}{c}18.00 \\
\pm 0.00^{c}\end{array}$ \\
\hline 1566 & & 15 & $\begin{array}{c}7.17 \\
\pm 0.00^{\mathrm{ab}}\end{array}$ & $\begin{array}{c}2.55 \\
\pm 0.00^{\mathrm{a}}\end{array}$ & $\begin{array}{c}1.63 \\
\pm 0.00^{\mathrm{bc}}\end{array}$ & $\begin{array}{c}2.81 \\
\pm 0.00^{\mathrm{bc}}\end{array}$ & $\begin{array}{c}15.67 \\
\pm 0.06^{\mathrm{d}}\end{array}$ \\
\hline 2066 & & 20 & $\begin{array}{c}6.90 \\
\pm 0.01^{\mathrm{b}}\end{array}$ & $\begin{array}{c}2.61 \\
\pm 0.01 \mathrm{a}\end{array}$ & $\begin{array}{c}1.64 \\
\pm 0.00^{\mathrm{bc}}\end{array}$ & $\begin{array}{c}2.64 \\
\pm 0.01^{\mathrm{c}}\end{array}$ & $\begin{array}{c}15.00 \\
\pm 0.00^{\mathrm{d}}\end{array}$ \\
\hline 67 & \multirow{5}{*}{ 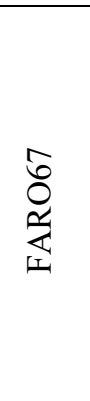 } & $\begin{array}{c}\text { Non } \\
\text { parboiled }\end{array}$ & $\begin{array}{c}6.97 \\
\pm 0.02^{b}\end{array}$ & $\begin{array}{c}1.98 \\
\pm 0.00^{d}\end{array}$ & $\begin{array}{c}1.94 \\
\pm 0.00^{\mathrm{a}}\end{array}$ & $\begin{array}{c}3.56 \\
\pm 0.01^{\mathrm{a}}\end{array}$ & $\begin{array}{c}21.67 \\
\pm 0.06^{b}\end{array}$ \\
\hline 567 & & 5 & $\begin{array}{c}7.23 \\
\pm 0.02^{\mathrm{ab}}\end{array}$ & $\begin{array}{c}2.10 \\
\pm 0.01^{\mathrm{c}}\end{array}$ & $\begin{array}{c}2.00 \\
\pm 0.00^{\mathrm{a}}\end{array}$ & $\begin{array}{c}3.45 \\
\pm 0.02^{\mathrm{a}}\end{array}$ & $\begin{array}{c}22.00 \\
\pm 0.00^{\mathrm{b}}\end{array}$ \\
\hline 1067 & & 10 & $\begin{array}{c}7.53 \\
\pm 0.03^{\mathrm{a}}\end{array}$ & $\begin{array}{c}2.37 \\
\pm 0.01^{\mathrm{b}}\end{array}$ & $\begin{array}{c}1.99 \\
\pm 0.00^{\mathrm{a}}\end{array}$ & $\begin{array}{c}3.19 \\
\pm 0.02^{\mathrm{b}}\end{array}$ & $\begin{array}{c}21.50 \\
\pm 0.05^{\mathrm{b}}\end{array}$ \\
\hline 1567 & & 15 & $\begin{array}{c}7.57 \\
\pm 0.03^{\mathrm{a}}\end{array}$ & $\begin{array}{c}2.23 \\
\pm 0.01^{\mathrm{c}}\end{array}$ & $\begin{array}{c}1.99 \\
\pm 0.00^{\mathrm{a}}\end{array}$ & $\begin{array}{c}3.42 \\
\pm 0.02^{\mathrm{b}}\end{array}$ & $\begin{array}{c}21.00 \\
\pm 0.00^{\mathrm{b}}\end{array}$ \\
\hline 2067 & & 20 & $\begin{array}{c}7.67 \\
\pm 0.03^{\mathrm{a}}\end{array}$ & $\begin{array}{c}1.96 \\
\pm 0.00^{\mathrm{d}}\end{array}$ & $\begin{array}{c}1.94 \\
\pm 0.00^{\mathrm{a}}\end{array}$ & $\begin{array}{c}2.58 \\
\pm 0.19^{c}\end{array}$ & $\begin{array}{c}16.33 \\
\pm 0.06^{\text {cd }}\end{array}$ \\
\hline
\end{tabular}




\section{Effect of steaming duration on the thousand grain weight $(1000 \mathrm{gw})$ of milled rice}

Thousand grains weight of rice measures the net weight of a randomly selected 1000 grains. It is important in evaluating rice yield and varietal differences, as well as a great impact on seedling viability and growth, though, correlated to kernel width, thickness and shape (Prasad et al., 2016). Un-parboiled sample had the lowest grain weight (15.67g), while sample steamed for $5 \mathrm{mins}$ weighed $24 \mathrm{~g}$. However, samples steamed between 10 and $20 \mathrm{mins}$ had decreased weight, corroborating the report of Gayin et al., 2009. However, for FARO65 variety, samples steamed for 20mins recorded the highest thousand grain weight (16.93g), $5 \mathrm{mins}$ steamed sample and control weighed $16 \mathrm{~g}$ and $15 \mathrm{~g}$ respectively, with significant differences within the samples. Pore sealing during steaming might have increased the weight (Prasad et al., 2018), and thus, increases rice thousand grain weight. Samples steamed for between $5 \mathrm{mins}$ were significantly different from samples steamed from 10 to $20 \mathrm{mins}$.

A significant difference $(\mathrm{p}<0.05)$ was observed in the grain weight of FARO66 samples, with the result ranging from $15-18 \mathrm{~g}$. Sample steamed for $20 \mathrm{mins}$ recorded the lowest weight $(15 \mathrm{~g})$, while $18 \mathrm{~g}$ was recorded in samples steamed for $10 \mathrm{mins}$. Un-parboiled sample weighed $17.33 \mathrm{~g}$. The values did not follow same pattern with increasing steaming-time, making it different to what was recorded in FARO65, though the mean values were not far from the range of 19.86-21.65g reported by Singh et al. (2002) and Prasad et al. (2018) in the unparboiled and parboiled samples steamed for 40mins. Thousand grains weight of FARO67 samples ranged between 16.33 and $22 \mathrm{~g}$, and was similar to what was recorded in FARO66. The control sample and samples steamed for 5 to $15 \mathrm{mins}$ were significantly different $(\mathrm{p}<0.05)$ from that steamed for 20mins. Un-parboiled (control) sample weighed $21.67 \mathrm{~g}$, and was noticed that steaming from 10 to 20 mins caused reduction in weight of the parboiled rice variety. To achieve a weighty grain in FARO67 variety, steaming for short periods was better. Also, reduction in grain weight might be due to poor pore fillings with water molecules as reported by Singh et al. (2002).

\section{Conclusions}

It should be noted that the proximate composition of these new rice varieties was comparable to those of existing rice samples worldwide, the study, however, looked at some parameters used to assess rice quality. Though some of the results were outside expectations, however, it can be concluded that steaming, as a unit operation in rice parboiling, has significant impact on the colour of parboiled milled rice, and improve the strength required to break parboiled rice during milling. Likewise, steaming period positively influenced rice grain dimension and quality, as witnessed in the varieties, where medium shaped ones changed to very long size when steamed for $15 \mathrm{mins}$, though sample size was not considered. For a good quality milled rice grains, rice properties must be considered during processing, as every rice variety has optimum processing requirement. However, in general, steaming for $15 \mathrm{mins}$ gave the best result, and thereby recommended.

\section{References}

Amaka M. O., Michael N., Chijioke E., Noe W., Sali, A. (2014), Physicochemical, cooking characteristics and textural properties of TOX3145 Milled Rice, Journal of Food Research, 3(2), pp. 82-90. 
Anuonye J.C., Daramola O.F., Chinma C.E., Banso O. (2016), Effect of processing methods on physicochemical, functional and sensory properties of Ofada rice, International Journal of biotechnology and food science, 4(1), pp. 7-14

Ayamdoo J.A., Demuyakor B., Dogbe W., Owusu R. (2013), Parboiling of paddy rice, the science and perceptons of it as practiced in Northern Ghana, International journal of scientific and technology research, 2(4), pp. 12-18

Bleoussi T.M., Roseline L., Mamadou F., Bokossa I., Koichi F. (2010), Effect of parboiling and storage on grain physical and cooking characteristics of some NERICA rice varieties, Seconf Africa Rice Congress, Bamako, Mali, 22-26 march 2010: Innovation and partnerships to realizeAfrica's Rice Potential University of Abomey Calavi, 01 B.P.2009, Cotonou, Benin.

Danbaba N., Anouye J.C., Gana A.S., Abo M. E., Ukwungwu M.N., Maji A.T. (2012), Physical and pasting properties of ofada rice (Oryza sativa) varieties, Nigerian Food Journal, 30(1),

Danbana N., Abo M. E., Hassan H., Nkam I. (2016), Processing characteristics, grain quality and end use quality of hybrid and common improved rice (Oryza sativa) varieties in Nigeria, International journal of agriculture and forestry, pp. 91-104.

Ebrahim T., Mohammed H.K., Saeid M., Asefeh L. (2015), Effect of soaking temperature and steaming time on the quality of parboiled Iranian paddy rice, International Journal of Food Engineering, 11(4), pp. 547-556

Ebuechi O.A.T., Oyewole A.C. (2007), Effect of cooking and soaking on the physical characteristics, nutrient composition and sensory evaluation of indigenous and foreign varieties in Nigeria, Africa Journal of Biotechnology, 6(8), pp. 1016-1020

Elbert G.M., Tolaba P., Suaez C. (2000), Effects of drying conditions on head rice yield and brown index of parboiled rice, Journal of Food Engineering, 47, pp. 37-41

Farah S., Mosin A. R., Muhammad A. (2017), Grain quality attributes of new rice basmati linesof Pakistan. Journal of Agricultural Researched and Development, 7(1), pp. 7584.

Fofana M., Wanvoeke J., Manful J., Koichi F., Van-Mele P., Zossou E., Bleoussi T. (2011), Effect of improved parboiling methods on the physical and cooked grain characteristics of rice varieties in Benin, International Food Research Journal, 18, pp. 715-721.

Gayin J., Manful J.T., Jonhson P.N. T. (2009), Rheological and sensory properties of rice varieties from improvement programmes in Ghana. International Food Research Journal, 16, p. 167-174

Graham-acquah S.J., Manful T., Ndideng S.A., Tchatcha D.A. (2015), Effect of soaking and steaming regimes on the quality of artisanal parboiled rice, Journal of Food Processing and Preservation, 39 (6), pp. 2286-2296.

Hossain M.S., Singh A. K., Fasih Z. (2009), Cooking and eating characteristics of some newly identified inter sub-specific (indica/japonica) rice hybrid, Science Asia, 35, pp. 320-325.

Hossain M.S., Singh A. K., Fasih Z. (2009), Cooking and eating characteristics of some newly identified inter sub-specific (indica/japonica) rice hybrid, Science Asia, 35, pp. 320-325.

Igathinathane C., Chattopadhyyay L.O.P. (2005), Combination soaking procedure for rough rice parboiling, America Society of Agricultureal Engineers, 4892, pp. 665-671.

International rice research institute (2009), Making healthier rice, Available at:

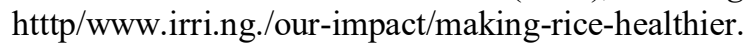

IRRI (2004), World Rice Statistics, International Rice Research Institute, Manila 


\section{- Food Technology —}

Islam M.D., Rabiul N.S., Toshiori K. (2000), Quality evaluation of parboiled rice with physical properties, Food science technologyresearch. 7(1), pp. 57-63

Joseph A.A., Amikizunu J., Razak A.A. (2015), Effect of varied parboiling condition on proximate and mineral composition of Jasmine- 85 and Nerica-14 rice varieties in Ghana, International journal of food research, 2(1), pp. 1-11.

Islam M.R., Roy P., Shimizu N., Kimura T. (2004), Energy requirement in parboiling and its relationship to some important Quality indicators. Journal of Food Engineering 63: 433-439.

Islam M.R., Roy P., Shimizu N., Kimura T. (2002), Effect of processing condition on physical properties of parboiled rice, Food Science and Technology Research, 8(2), pp. $106-112$.

Marshall W.E., Wadsworth J.I., Verna L.R., Velupillai L. (1993), Determining the degree of gelatinization in parboiled rice: comparison of a subjective and objective method, Cereal chemistry, pp. 226-230.

Mayowa S. S., Rahman A., Danbaba N. (2019), Evaluation of physical, milling and cooking properties of flour new rice (Oryza sativa L.) varieties in Nigeria, International journal of food studies, 6, pp. 245-256

Prasad C., Sajeev R. S., Taesen M., Gulshan M. (2018), Effect of parboiling techniques on physicochemical and nutritional characteristics of basmatic rice, Agricultural Research journal, 55(3), p. 490

Prem S. Y., Palaninmuthu V. (2019), Effect of steaming on accelerated aging of rice (oryza sativa L.), International journal of current microbiology and applied science, 8(2): $358-375$.

Sareepuang K., Siriamornpun S., Wiset L., Meso N. (2008), Effect of soaking temperature on physical, chemical and cooking properties of parboiled fragrance rice, World Journal of Agricultural Science, 4 (4), pp. 409-415.

Singh K.R., Singh U.S., Khush G.S. (2000), Aromatic rice, NewDelhi.

Singh N., Pal N., Mahajan G., Singh S., Shevkani K. (2011), Rice grain and starch properties: effects of nitrogen fertilizer application, Carbohydrate polymers, 6(1), pp. 219-225.

Singh N., Sodhi N.S., Kaur M., Saxena S.K. (2003), Physic0chemical, morphological, thermal, cooking and textural properties of chalky and translucent rice kernels, Food chemistry, 82(3), pp. 433-439.

Sunday E.K., Bayode J.O., Babatunde S. (2018), Determination of engineering properties of some Nigeria local grain crop, International journal of agricultural and biosystem engineering, 3(1), pp. 10-18

Varnamkhasti M.G., Mobli H., Jafari A., Keyhani A.R., Soltanabadi M.H., Rafiee S., Kheiralipour K. (2008), Some physical properties of rough rice (oryza sativa L) grain, Journal of Cereal Science, 47(3), pp. 496-501.

Vikrant K., Jaivir S., Neelash C., Suresh C., Vivak K., Yadav M.K. (2018), Processing of paddy parboiling and their effect on rice, Journal of pharmacognosy and phytochemistry, pp. 1727-1734. 